\title{
ECOSYSTEM SERVICES AND THEIR IMPACT ON POVERTY AND INEQUALITY IN COASTAL COMMUNITIES OF BAJA CALIFORNIA SUR
}

\author{
E. MARÍN-MONROY \& J. URCIAGA-GARCÍA \\ Universidad Autónoma de Baja California Sur., Mexico.
}

\begin{abstract}
Poverty is a complex social problem that directly affects the sustainable management of many ecosystems in Mexico. Baja California Sur has focused its economic and demographic development on the coastal zone. This offers benefits, principally material and cultural, through ecosystem services that must be valued to promote conservation. It is currently recognized that marginal communities greatly depend on natural resources. This study diagnoses poverty and the effect that certain ecosystem services have on improving income distribution in some localities. A methodology for measuring multidimensional poverty through a disaggregated index was adopted. This study sets out a new future focus on multidimensional measuring that uses, in addition to income, dimensions or variables that influence the well-being of the population. Finally, Gini coefficients were obtained to measure inequality. Smaller communities dependent on ecosystem services had a higher poverty level, while ecosystems had a positive effect on improving the distribution of wealth. These services encourage sustainable development, which in turn drives the efficient use of natural capital and promotes social equality.

Keywords: Conservation, ecosystems, indicators, multidimensional poverty, valuation, well-being.
\end{abstract}

\section{INTRODUCTION}

\subsection{Background}

Ecosystem services (ES) and their impact on human well-being form part of a recent analytical framework proposed by Costanza et al. [1] and taken up by various authors [2-5]. Upon reaching a broad consensus in the scientific community, a document emerged titled Millennium Ecosystems Assessment [6]. It has become the basis for many studies aimed at placing greater value on the services provided by ecosystems, taking into account not just their useable or market value but also their intrinsic value. These services provide social and cultural benefits such as recreation and inspiration.

This focus coincides in some aspects with the focus on poverty based on Sen capabilities [7], which favor the existence in man of free agency, or the use of certain resources in the environment to achieve his ends. In coastal areas, it is common for part of the population to dedicate itself to activities oriented towards the primary sector, such as fishing, agriculture, raising livestock and other activities in tertiary sector such as tourism and recreation. This creates an environment of internal development where the inhabitants of the community generate their own income and a dignified way of life. A self-identity arises in each area that promotes social cohesion and security. However, many primary activities designated as provisioning under ES are undervalued and bring a low level of income. This ties the social sector to a vicious cycle that generates greater dependence on natural resources and encourages the unsustainable use of them.

To incorporate the social aspect into the subject of sustainable management, a holistic approach that is self-sustaining and generates better results is suggested. Since 1993, UNESCO has highlighted 
the importance of utilizing social indicators for integrated coastal management and has proposed using some indicators that link population and the use of ES [8]. Some examples of these indicators are: coastal population, economic valuation of tourism activities, and distribution of the benefits of ES within the population, among others.

The theme of poverty and with it inequality, exclusion, and social marginalization hold special relevance due to the fact that in recent years they have been considered that poverty is a condition that has a negative impact on the environment $[9,10]$. The population with greater material shortages is more dependent on natural resources since its planning horizon to attend to its needs is reduced to what is immediately important. This negatively impacts sustainable development [11].

\subsection{Ecosystem services and poverty reduction}

ES flow from stocks of natural capital that are divided into four main types: provision, regulation, culture, and support. A direct link is established between social well-being and the services, generating social benefits (economic and perceptual).

The greater the quantity and quality of the ES, the greater the access a society will have to those benefits. A society will derive greater well-being or, alternatively, a reduction in poverty. In the case of India, Jodha [12] found that up to $25 \%$ of incomes is derived from natural resources and that this percentage increases where greater poverty exists, generating even greater dependency in this sector of population. Policies to combat poverty have not yielded the results hoped for as the number of poor people increases year over year. It has become vital to focus on conservation and the sustainable use of common resources. This has been reinforced by Dasgupta [13] who, from the perspective of economic development, established a link between environmental protection and the well-being of the poor. Although the analysis of global economic value is important, one of the objectives of analyzing poverty in a regional context is to recognize the importance of the social value of natural resources. The social value is often superceded by direct economic value $[14,15]$. The analysis should incorporate the interaction between social aspects and ecosystems.

As for establishing the source of environmental degradation, there exists a conflict among several authors. Some attribute it to the state and its institutions more than to flaws in the market and the circumstances of poverty $[16,17]$, whereas others attribute environmental degradation precisely to the poverty of the communities immersed in ecosystems. Additionally, it is recognized that one of the critical conditions necessary for achieving sustainability is to have low levels of poverty [18].

Regarding the ES in Baja California Sur (BCS), the marine ecosystems in the Gulf of California and the Pacific Ocean provide one of the most important provisions: fisheries. However, the marine ecosystems also contribute cultural services such as recreation and tourism, the cultural formation of fishermen, farmers, ranchers, and craftsmen, as well as information for cognitive development and research. Small-scale fishing has become a safety net for the poor, which includes not just coastal fishermen but also the economically displaced and immigrants, as has been documented in fishing communities in BCS [19].

Studies that have been undertaken in BCS about this topic are scarce and are related to the management of protected areas, notably the estimate of the poverty index (IPH) in the community of Cabo Pulmo [20]. Other research concluded that there exists evidence of deep poverty in San Jorge, a community in a protected area in BCS [21]. Finally, Urciaga [22] has suggested a focus on the valuation of the services that solve the false conflict between development and conservation, with natural capital being the key to combating poverty. 
1.3 Poverty identification and measurement: from the classic to the multidimensional approach

The first definitions of poverty were centered on the inability to obtain enough food as well as other basic needs that allow the individual to exist. They are also known as the biological approach. Nowadays, poverty refers to the deprivation of the necessary elements for human life within a society as well as resources to modify this situation. In other words, it takes into consideration food and basic goods as well as the need for humans to take an active role in society such as getting a job, studying, and participating in activities within their own community. This approach is known as the basic needs approach. The concept of poverty in relation to society can be referred to in absolute or relative terms. The type of society requires a corresponding standard of living. In this approach of relative deprivation, scarcity depends on people's needs.

The measurement of poverty can be broken down into two stages: identification, where criterion is defined to make a distinction between poor and non-poor people and aggregation, which is the compilation of poverty data for a global indicator of poverty [23]. The income approach measures identification with the method of poverty lines, in which it is the family and not the individual that is the natural unit of consumption. This also requires a method of correspondence between family and individual income. This method distinguishes between three types of poverty: food poverty, capabilities poverty, and asset poverty, all of them based on different baskets of goods and services. On the other hand, to measure aggregation, indicators are obtained from a variety of methods such as simple radius, or the percentage of poor people in a determined population, the poverty gap per capita or the method of family aggregation FGT [24], which satisfies a series of properties such as symmetry, non-variation in rebuttals, consistency of subgroups and disaggregating.

The new concepts of poverty not only measure monetary aspects but they also adopt a multidimensional approach [25] where income is not as important as living conditions or lifestyle. Well-being and quality of life are favored by this approach, which makes emphasis on the capabilities acquired, with income, health, education, empowerment, and human rights being the most important. These dimensions will grant freedom and self-worth to people. Each capability represents one dimension and it can be measured through different variables. This focus on capabilities, which offers a more holistic way to measure poverty, is the most accepted in developed countries. The measurement in the multidimensional approach can be made in a variety of ways, like taking into account multiple indicators of welfare that result in one variable. Another way is through the union of each dimension; with this approach, if a person is poor in one dimension, he turns into a multidimensional poor person, which can overrate the value of poverty even though it promotes equitable development [26].

Outside the context of identification and aggregation of poverty, indicators to measure the degree of well-being of a determined population have been developed to express the degree of advance or regression achieved based on the variables used. Some examples of these indicators are the index of human development (IHD), the index of human poverty, and the index of marginalization calculated by the National Population Council in Mexico (CONAPO) at the state level.

One of the advantages of multidimensional measurement is that it evolves to incorporate less income-related aspects that affect the lives of families. The phenomenon of poverty represents a social problem that impacts directly the sustainable management of numerous ecosystems in Mexico, because the ES provided substitute the income and improve the well-being of the population. One of these services is provision, which provides food, fuel, handicrafts, and construction materials, among others. 
The indicators used these days come from the acknowledgement that the approach of the poverty lines should be expanded to incorporate elements usually not considered, such as the value of leisure time, services provided by infrastructure, and complementing it with non-monetary [27]. A personal proposal is to incorporate the use and monetary value that is provided by ES, since they can really make a difference, especially in rural communities, where according to the figures by the conventional measurement of poverty, $34.1 \%$ of the population cannot access the basic food basket, against $9.8 \%$ of the urban population. As a consequence, natural resources and natural capital are used by the population to resolve their basic needs such as food and recreation, thus achieving social wellbeing.

Therefore, it is important to focus on detecting multidimensional poverty in every community and to detect what variables affect them in a greater number. Otherwise, the researcher can falsely believe that he is starting from their point of view when he is not. Also it is important for a scientist to abandon the prejudices of his own subculture to be able to capture the reality of the subculture he is studying. Finally, it is important from the point of view of communicational ethics that indicate that in order to guarantee respect, research must include the point of view of the one being investigated [28].

The present study examines the impact of integrating the economic value of coastal ES into family income to improve the indicators of social welfare. To this end, three objectives were established, first we characterized poverty by available indicators of the state and municipal level. In the second place, poverty in coastal communities is defined using multidimensional measurements that represent an improvement over traditional methods, offering a guideline to generate more informed decisions in the process of managing natural resources. Finally, inequality measured the study area to compare whether there was an improvement to include in income the value perceived and declared ecosystems. By taking into account such variables, we can advance local sustainable management by linking social welfare benefits provided by ecosystems.

\section{METHODS}

\subsection{Study area}

The study area is situated along the coastal corridor of the Gulf of California, from the Bay of La Paz to the zone known as La Ventana. The towns contained therein are El Centenario, Chametla, La Paz, El Sargento, and La Ventana (Fig. 1). Some $25 \mathrm{~km}$ in front of the eastern part of the Bay of La Paz lies the Espíritu Santo island complex, which forms part of the protected marine area 'Islands of the Gulf of California'. It includes more than 900 islands and islets, which make up approximately $50 \%$ of the national island territory and represent a zone of refuge and habitat for diverse marine species [29].

This coastal corridor has 223,265 inhabitants, which is more than one-third of the state total, and shows dynamic growth that is above the national average (Table 1). The traditional economic activities are coastal fishing, agriculture, and recently business based on tourism and recreational activities. A good measurement of poverty and inequality over time and between groups and sectors permits decision-making based on factual evidence. It drives good policy design for social and economic development. It is important to create disaggregated indicators that can increase the efficient use of resources and focus the enjoyment of benefits.

Economically, there are vast differences between states in the northern and southern regions of the country. The state of Baja California Sur, within a monetary focus, is one of the least poor in Mexico. This situation does not inspire confidence since despite occupying a privileged position, there exists poverty among the inhabitants that can grow due to economic immigration and an increase in the population growth rate. The county of La Paz is one of the most highly populated in the state. 
Table 1: Population by location or town and growth (2005-2010).

\begin{tabular}{lccc}
\hline Location or town & Population 2005 & Population 2010 & \% Growth 2005-2010 \\
\hline La Paz & 189,176 & 215,178 & 13.7 \\
El Centenario & 3,626 & 4,696 & 29.5 \\
Chametla & 1,731 & 2,178 & 20.5 \\
La Ventana & 183 & 255 & 39.3 \\
El Sargento & 836 & 958 & 14.6 \\
Coastal Corridor & 199,552 & 223,265 & 11.9 \\
\hline
\end{tabular}

Source: CONAPO, 2005, 2010.

It contains the Bay of La Paz-La Ventana corridor, whose coastal population represents $93.4 \%$ of the total population. This variable is registered as a pressure on the use of natural resources. It is important to consider demographic aspects since population growth has a bearing on monetary and natural resources [30]. According to CONAPO, the population in BCS grew 20.8\% from the year 2000 to 2005. The tendency has not reversed as the most recent data from National Institute of Geography and Statistics (INEGI) [31] show that state population growth accelerated from 2005 to 2010 at a rate of $24.3 \%$. For its part, the county of La Paz maintained growth of $11.9 \%$.

The La Paz-La Ventana corridor has a high level of tourism employment, as well as a large number of cultural ES. A survey with two principal objectives was taken. The first was to know about the impact that ES have upon the well-being or the reduction of poverty for the inhabitants, through the declared and perceived value of the ES. The second was to obtain information to estimate the Multidimensional Poverty Index (MPI) using indicators of health, education, and quality of life.

\subsection{Methodology}

Secondary information was collected from the following sources: The Secretary of Social Development (SEDESOL), The National Population Council (CONAPO), and INEGI. The first is in charge of formulating and administering social policy to combat poverty in Mexico, while the other two provide population statistics. The Marginalization Index is used as a reference because it is the only proxy indicator for poverty of the local level. Its advantage is that it summarizes the shortages that the population suffers from. The Census of Housing and Population is used as a highly trustworthy source of information. However, there can occur an underestimation of the marginalization since the greater part of the aspects are related to access to housing services, such as potable water, sewage, and electricity where good coverage exists in the region.

To complement statistical information, a survey was conducted from September to December 2011. It was applied in 130 family homes and includes information from 445 residents of the study area, the number of surveys applied was determined in software MiniTab with significance statistic of $95 \%$ according to the standard deviation and the mean. The survey uses a random sampling technique stratified with proportional assignment according to the number of inhabitants in the places studied. The survey was conducted in the form of face-to-face with the head of household or a person over 18 years with a response rate of $98 \%$. The objective was to collect information to obtain a MPI based on Alkire and Santos [32]. It incorporates indicators that improve the understanding of information. Two aspects that it measures are: weekly recreation hours and the body mass index (BMI) calculated from the weight and height reported by respondents. These improve 


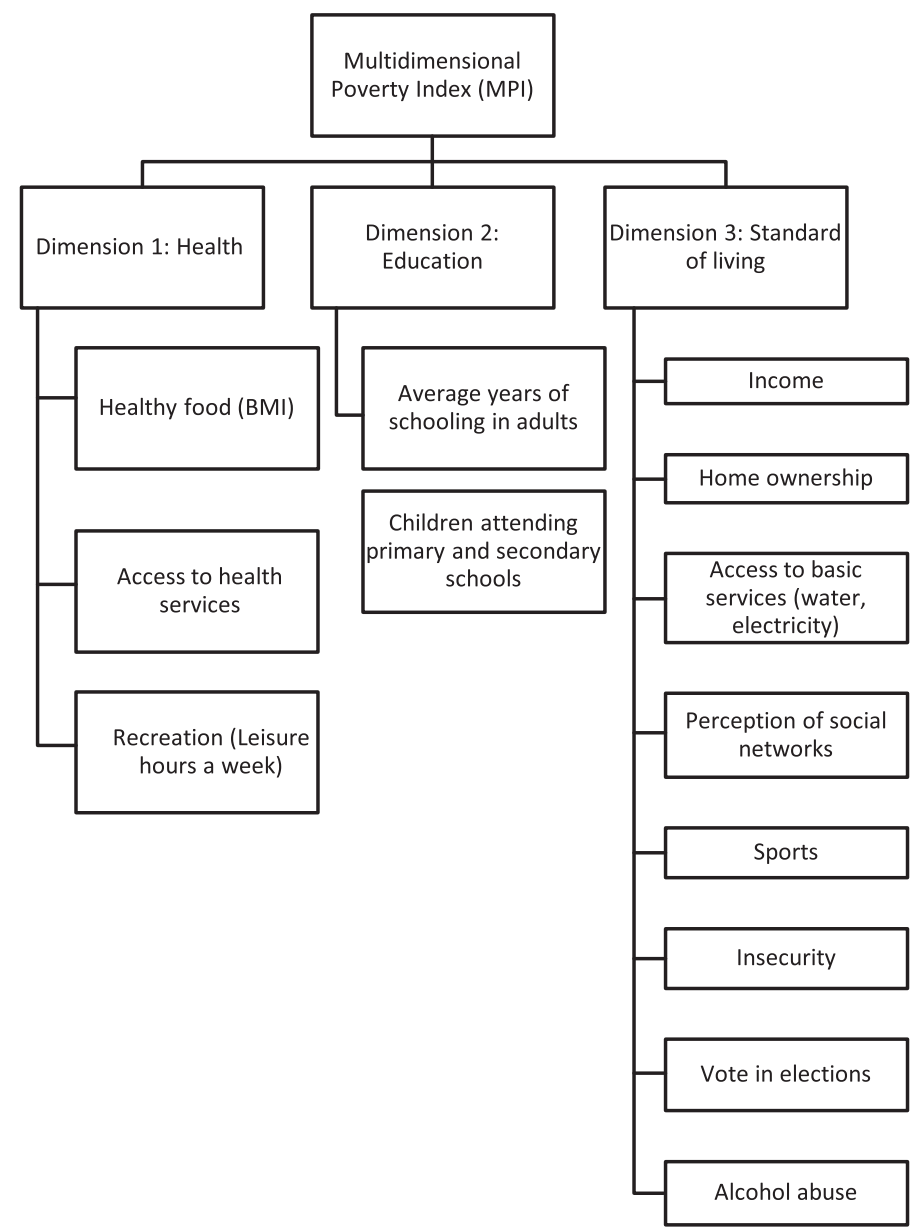

Figure 1: Multidimensional poverty index: dimensions and variables. Source: authors elaboration.

the evaluation of the health aspect, as well as the perception of social networks, insecurity, voting rights, participation in sporting and social clubs, alcoholism, and home ownership. These represent variables that improve the evaluation of the aspect of the quality of life (Fig. 1). The resulting MPI has the objective of showing more information about the aspects that generate greater vulnerability in the inhabitants of each one of these localities and to generate policies focused on promoting sustainable development.

The MPI of the area and selected locations was calculated by a dual system. First, find out if the family has a deprivation in each of the indicators. If the answer is positive, it is given a value of 1 . If the answer is negative, it is given a value of 0 ; the range of MPI is $0-1$. The assigned weights of every positive answer are added to determine if the family is multidimensionally poor. Was assigned equal weight to each dimension and the weight was distributed on the variables that comprised each dimension (nested structure) [32]. In the case of BMI, the range of 18.5-24.99 was used, for not deprivation [26, 32], and for leisure time, the range from 24 to $48 \mathrm{~h}$ per week was taken [33]. For income, the poverty line for rural and urban population was used [31]. For schooling in adults, the poverty line is nine years (primary and secondary schools are obligatory). 
To determine the line of multidimensional poverty, as the MPI reflects an average of household deprivation, it was necessary to consider that the householders are also motivated by their own preferences. For instance, they can sacrifice their recreation time to increase their working hours, or they may have a BMI out of the norm because of their genes. Therefore, they have deprivations in those variables, but it does not necessarily imply that there is poverty in the home. Experts in the field suggest that a household is classified as poor, when you lack in $30 \%$ of its variables $[26,32]$, that is why a $k=3$ system was chosen, where $k$ is a variable that reflects the sum of the indicators in which the home has deprivations. If the community or homes have a $30 \%$ or more deprivation in their indicators (indicators may vary from 2 to 8 ), it is considered multidimensionally poor since the concurrence in several indicators tells us that there is a smaller degree of well-being.

The survey also permits knowing about the monthly declared monetary value of two types of ES: provision and recreation. For the first, the following goods are taken into account: food, fuel, medicinal herbs, and construction materials. The survey assigned a value based on market prices to estimate how much would have been paid monthly of not receiving it free as an ES. This value represents an income substitute that permits one to know the impact on well-being in each home and on the poverty index in the communities studied. Measurement of this impact on the local level was obtained by calculating the Gini coefficient, one of the most used indicators to measure equality. It takes into account average family income, first the income was taken into account (e.g. salaries and rent) and second, the income the monetary value declared for ES was included. Finally, the two resulting indicators were compared. The calculations were done using the software DAD 4.6 [34].

\section{RESULTS AND DISCUSSION}

\subsection{Analysis of the available indicators of poverty and development in Baja California Sur}

CONEVAL measures poverty in Mexico and calculates it by income. Poverty is divided into three types according to magnitude: food poverty, capability poverty, and asset poverty. These data show that in 2005 in BCS $4.7 \%$ of the population suffered from food poverty, $8.0 \%$ from capability poverty, and $23.5 \%$ from asset poverty. In absolute numbers that places 24,072 inhabitants in food poverty, 40,974 in capability poverty, and 120,360 in asset poverty. Comparing these data with those from the year 2000, there was a reduction in poverty in percentage terms as well as absolute numbers. Taking into account the growth in population, this can be explained by government support through programs aimed at poverty reduction.

Beginning in 2008, CONEVAL adopted, in addition to poverty measurements based on income, a methodology to measure poverty in its multidimensional form that takes into account the diverse shortcomings that the population suffers from, not just income. CONEVAL adopted two thresholds for poverty, one for income and the other for deficiencies. People above these lines are not categorized as poor, people below these thresholds are categorized as multidimensional poor, and people who fall below only one standard are considered as vulnerable. In 2008, $21.1 \%$ of the population in BCS was considered multidimensional poor. However, in more recent data from 2010 the population not poor vulnerable was $31.1 \%$, the income vulnerable represented $4.5 \%$, the vulnerable based on social shortcomings was $33.5 \%$, moderate poverty was $26.3 \%$, and extreme poverty $4.6 \%$. This situation is worrying because the number of people in moderate poverty increased $51.74 \%$ and the numbers of extreme poor increased 85\% from 2008 to 2010.

Another important indicator by location is the Marginalization Index calculated by CONAPO, which includes the measurement of the following variables: years of education, housing characteristics, and the percentage of the economically active population that earns less than two minimum 
salaries. However, the latest measure of the income variable was not taken into account, making it less complete. In this indicator, BCS lost places on the national list, from 27 in 2000 to 24 in 2005 (with 32 representing the lowest marginalization). At the county level $\mathrm{La} \mathrm{Paz}$, which contains the Bay of La Paz-La Paz corridor, finds itself with a very low level of marginalization [35]. Nevertheless, data for each location often differ from that at the county level. For the year 2010, the Marginalization Index was not published. Its place was taken by a similar indicator formulated by CONEVAL called the Index of Social Backwardness. According to this index, BCS occupies the 21 st place with a low level of social backwardness. The index was also calculated for 2005 , in which BCS held 22nd place, representing an improvement.

Finally, based on another indicator, the IHD, BCS falls in the category of high human development (IHD greater than or equal to 0.80 ). The position of BCS in a national comparison has improved from place 6 in the year 2000 to place 5 in 2005. In relative terms for the year 2005, the state IHD was 0.8515 , while the best national value was 0.8200 [36]. This has the disadvantage that there exist no local data.

\subsection{Multidimensional poverty measurement in communities located in the coastal corridor La Paz-La Ventana}

BCS130 surveys were collected from homes in the main coastal locations: La Ventana, El Sargento, La Paz, Centenario, and Chametla. These surveys include data from 445 individuals, a number that exceeds the minimum reference sample of finite population. With regard to the source of income, it refers to any activity that generates remuneration for the families. The calculations of monthly income include: salary, rent, benefits, scholarships, and financial support (such as the program Opportunities), as well as the calculated amount of the benefits granted in kind by the ecosystems. It is important to know expressed monetary value of ecosystems and begin to promote a better conscience and care in the natural resources for extended benefits to next generations.

As a result, $85.4 \%$ of the householders interviewed claimed to have a job, and $79.7 \%$ claimed to have a permanent job. $20.3 \%$ of the total householders have a temporary job and work from 6 to 11 months a year. The average income of the sample without considering the ecosystems was $\$ 12,639.86$ pesos per month (around 972 dollars), whereas the average of the sample that includes the value of ecosystems was a total of $\$ 13,677.36$ per month (around 1,052 dollars). It represents an $8 \%$ increase in the family income.

Table 2 shows the values obtained in the measurement of poverty in the communities in the La Paz Bay-La Ventana, BCS coastal corridor. In addition to the MPI, other indicators were calculated as the incidence of poverty represented by $\mathrm{H}$, and the average of deprivation in poor homes represented by $\mathrm{A}$.

For the communities of El Sargento-La Ventana, the MPI resulted in a value of 0.3061, putting it near the limit. However, it is considered multidimensionally poor. The previous idea is complemented by the counting of poor households or poverty incidence, which is measured by $\mathrm{H}$, a complementing indicator that notes that $68 \%$ of the people surveyed suffer multidimensional

Table 2: Indicators of poverty per location.

\begin{tabular}{lclc}
\hline Location/area & MPI & \multicolumn{1}{c}{ H } & A \\
\hline La Paz & 0.2660 & 0.3734 & 0.3765 \\
El Sargento/La Ventana & 0.3061 & 0.68 & 0.3860 \\
Centenario/Chametla & 0.3414 & 0.61 & 0.3962
\end{tabular}

Source: Own elaboration. 


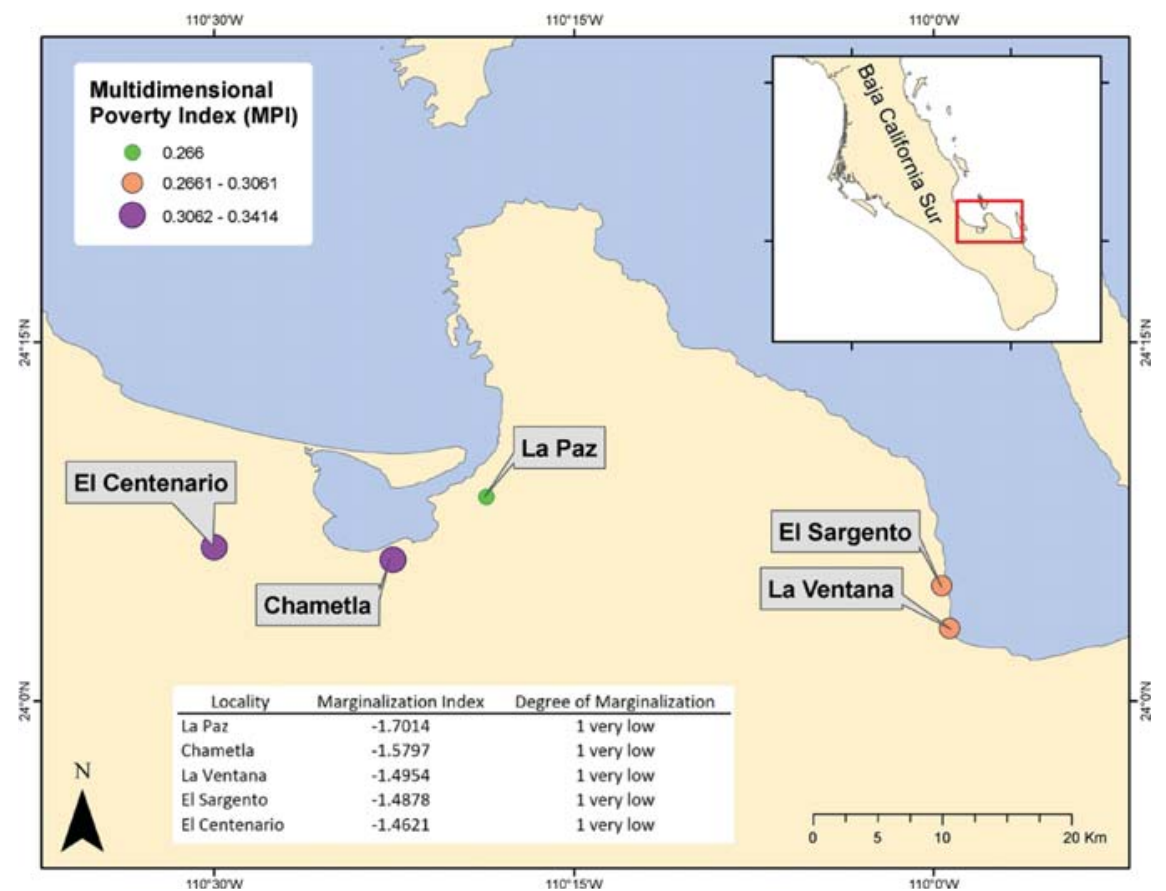

Figure 2: Multidimensional poverty index and degree of marginalization by location in the La Paz Bay-La Ventana coastal corridor communities. Source: Compiled by author.

poverty. The variables that affect them mostly in descending order are: adult education, recreation, nutrition, and access to health services. In terms of the intensity of poverty, which is measured by A, these locations have an average backwardness of $38.6 \%$ of their indicators.

In the case of La Paz, the MPI is smaller and has a value of 0.2660 , which takes it out of the classification of a multidimensional poor city. However, the percentage of people who live in this condition is $37.3 \%$ of the total population. It is also stated that poor people from La Paz have less deprivations compared with the poor people from other locations.

Finally, for communities like Centenario-Chametla, the PMI was 0.3414, which shows that the population from the area is multidimensionally poor. The incidence is $61 \%$ of the families, and a high intensity of $39.6 \%$ of deprivation in the indicators of poor households. The indicators that affect them mostly are: adult education, healthy nutrition, recreation, and the perception of social networks.

In a comparative analysis, the locations that belong to the La Paz Bay-La Ventana coastal corridor are well positioned taking into consideration the Marginalization Index (CONAPO) that classifies them as 'very low marginalization'. Nevertheless, there is contradictory data, since the most recent measurement of multidimensional poverty in the state increased considerably mainly in extreme poverty (Fig. 2).

\subsection{Ecosystem services and inequality}

For ES, the families surveyed reported an average value of \$ 1,037 pesos (about 86 dollars) monthly if we extrapolate to all families in the La Paz-La Ventana coastal corridor, representing nearly 58 million pesos per month (4.8 million dollars). 
Table 3: ES impact on inequality indicator.

\begin{tabular}{lc}
\hline Index & La Paz Bay-La Ventana \\
\hline Gini without ES & 0.45 \\
Gini with ES & 0.43 \\
Difference & 0.02 \\
\hline
\end{tabular}

Source: Author's data

To measure the impact of ES in the improvement of income equity, the Gini coefficient was calculated in the coastal corridor with DAD Software at the confidence level of 95\%. We calculate the Gini coefficient taking into account the income variable in each household, and then including the declared value of the ES in the income variable. The results are shown in Table 3. In this case, the well-being in communities was improved by reducing the Gini coefficient that included ES.

\subsection{Discussion}

Baja California Sur has been a region protected by policies focused on natural areas. However, for such protection to be successful, it is necessary for the population in these areas to be convinced of the potential benefits that can be generated. Moreover, it is necessary for the planning process to be guided by an integrated vision that includes social, economic, institutional [37], and environmental variables. A limit to this type of planning is that there exist no indicators to measure the social aspects that are tangible and not just based on perception. A key indicator in other parts of the world measures poverty by locality. Identifying the number of inhabitants that suffer from poverty as well as the magnitude of poverty is vital to improving the quality of life in a region, but the detection and subsequent mitigation of said poverty is currently not possible. The knowledge of poverty is indispensable for feedback and monitoring of management programs. It reveals the reach of these policies and whether they fulfill one of the principal stated objectives: to improve the quality of life of the inhabitants.

Until now, BCS has been one of the states with the low indices of marginalization and poverty, taking into account the available poverty indicators based on municipal aggregation. By analyzing marginalization by locality, it was found that in the county of La Paz $46.3 \%$ can be classified within the range of high marginalization. The above is worrying because La Paz is the county with a larger population, the greater part of which is concentrated on the southern strip of coast. One selection factor of the study area is the greater economic dynamism linked to the use of coastal ES such as fishing, low-impact tourism, and recreational activities.

Measuring multidimensional poverty includes income as well as other variables that improve well-being. This not only achieves identifying vulnerable towns and individuals but also makes it possible to propose actions to mitigate poverty where the effort is merited. This will generate greater benefits for actors involved in the conservation of marine and coastal ecosystems. Another advantage of the multidimensional measuring approach is that it allows structural recommendations that break the mechanism of long-term intergenerational perpetuation of poverty [38].

A limitation on the income-based method is that it treats the topic of poverty as a lack of money and does not take the individual into consideration. As a consequence, poverty can become a social issue. In relation to this, Bourguignon [39] points out that income poverty has been reduced in many developed countries but it has not stopped social exclusion. Recently, the issue of poverty has been looked at from the point of view of human development [40, 41]. Where poverty does not only mean 
the lack of the necessary things to achieve material well-being but also includes other aspects that impact directly and negatively the development of present and especially future generations. This implies that there is a lack of alternatives or opportunities for human development, thus making it impossible to live a long, healthy, creative life in which a decent standard can be enjoyed with freedom, dignity, self-respect, and respect for others.

In the case of Mexico, the studies on poverty have evolved from a one-dimensional $[42,43]$ to a multidimensional approach, but only to a national level [44-46]. Some aspects that motivate this last analysis are that it acknowledges that there are no markets for certain goods, like public goods [47] and the criticism raised in some international forums to certain established indexes. The legal sphere is also heading towards multidimensional measurement, according to article 36 of the General Law of Social Development published in 2004, which states that poverty should be calculated with information provided by National Institute of Statistics, Geography and Informatics (INEGI), considering also the following dimensions: (i) income per capita, (ii) average educational deficiencies, (iii) access to health services, (iv) access to social security, (v) housing quality and space, (vi) access to housing commodities, (vii) access to nutrition, and (viii) degree of social cohesion. The National Council of Assessment of Social Development Policy (CONEVAL) was created for this task and since 2009 it has carried out a methodology for the measurement of multidimensional poverty at the state level.

CONEVAL'S methodology attempts to incorporate social rights, such as the right of education, to the protection of health, to an adequate environment, to housing, children's rights, the right to work, to nutrition, and to access of water [48]. All these rights are observed internationally and most of them are part of the Mexican constitution.

The Secretary of Social Development (SEDESOL) is in charge of social programs designed to help the most vulnerable sectors in Mexico. The most important program with the greatest resources that SEDESOL manages is called Opportunities. This program offers conditional economic support to families in the most extreme conditions of poverty, a disadvantage of this type of program policy is that only solves the problem in the short term, while multidimensional measurements of poverty permit making structural recommendations that break with the mechanisms of perpetuating intergenerational poverty.

In the study area, the variables that affect the MPI are adult education, nutrition (BMI), and recreation. Although there is a national literacy policy, it has not yielded the expected results, probably because most of the population work in the primary sector and do not require a high level of education. In the case of nutrition, BCS are the greatest rates of obesity in both children and adults patterns of consumption and sedentary lifestyle [31]. Factors such as income level and education that can affect the BMI [49], in the case of the communities studied, were also affected by such actors.

Adding a monetary value to the ES does not help your little care cultural assessment, but it is a first step to sensitize society; this idea is reinforced by Howarth and Farber [50] when they pointed out the necessity of incorporating the value of services that are not connected to the market but that the population perceives directly relate to their well-being. One example is the cultural benefits and the landscape that provides recreation and inspiration for a healthy development of the inhabitants of a community, which strengthens the development of indicators to measure several dimensions of wellbeing or the lack of it, and as a consequence, we focus on an approach of functions and capabilities.

Besides including natural capital in the measurement, it is important to incorporate the social capital that becomes the glue that holds society together [51]. Their separation is reflected in more crime, more violence, family breakdown, etc. One way to include it (social capital) is by taking into account social cohesion. This indicator, according to Alaluf [52], makes reference to inclusion versus exclusion, to have opportunities to progress, to be able to participate in decisions that condition and relate to the 
organization of society. Its measurement is one of the main challenges within the territorial context dimension. It incorporates the use of unreliable or non-existent statistical data about behaviours that violate the rules. However, an effort must be made to include this type of indicator. There are some common social traits within the culture of poverty, such as a losing or defeated attitude, devoid of moral, unrealistic ambitions, without survival strategy, inconsistent, and lacking planning [53]. Since there is no planning, the population of poor regions prefers the financial benefit of an activity in the present rather than a greater or sustainable benefit in the future, which represents an obstacle for the responsible use of natural resources of common use, such as the coastal and marine ecosystems. In the study area, only the communities of Centenario-Chametla had low social cohesion, according to the survey of perceptions of social networks; in most communities, there is a healthy social environment.

The area studied is one of the most populated and, therefore, it is important to start on a local scale to measure poverty. Every community has its own characteristics and has a series of ES that can differ between them. Also, according to their diversity of economical activities, they may depend on a larger scale ES for their subsistence.

With regard to the dispersion of the sample data, there are values well above the average income, which indicates inequality in the distribution of income among the families living on the La Paz Bay-La Ventana Coastal corridor. In order to access this indicator, the Gini coefficient was obtained with DAD software, which was 0.45 for income without taking into account ecosystems and 0.43 for the income that includes the studied ES contribution. Despite the inclusion of these, improving the distribution of income among the sample population, the values obtained show a high lack of concentration of income in a few households. This situation prevails on a national level, since the last data published of this quotient were of 0.506 in 2008 [54].

In Mexico, there are few published studies about the contribution of common-use resources, such as water, forests, and seas, to the income of the poor. In the case of the southern region of the country, a study by López-Feldman et al. [55] shows that the population with a greater or extreme level of poverty receives greater improvement to its well-being once it exploits one of the common-use natural resources available in the zone, to include income from natural resources, economic inequality is decreased, the Gini coefficient was 0553 to 0583 , with a difference of 0.028 , similar to the results obtained in this study.

\section{CONCLUSION}

Current indicators of poverty show that BCS, in a national context, has low levels of poverty. However, population and environmental pressures exist in tourist destinations like La Paz, which is located on the coastal strip. Accelerating population growth is accompanied by the growing demand for goods and services, such as a growing demand for land, changing the landscape and land use. Current public policies seek sustainable development and, therefore, a strengthening of measuring poverty is indispensable, which implies a greater disaggregation of the indicators. In BCS, due to its patterns and characteristics of development, it is important to add to this measurement certain multidimensional aspects like the value granted to different users by coastal ES, principal among them recreation, ecotourism, and foodstuffs collected from marine sources. By means of a correct identification of vulnerable localities and sectors, decisions can be taken that generate actions and policies focused on these communities, creating greater equality between the population and development.

Taking into consideration that ES contributed to reduce the inequality in the coastal corridor, these suggested indicators may provide useful information for making decisions in terms of the management of natural resources. Monitoring these variables may help us design strategies to focus the benefits of ES on the most marginalized families and, then, make a positive impact on the local indicators of well-being. 
There is also an interesting finding. Communities such as La Ventana and El Sargento, where medium impact tourism activities are predominant, with an important influx of mainly foreign tourists that look for recreational activities such a sports fishing, windsurf, and camping, should generate positive benefits for the area. However, they had an MPI that placed them as a poor location and one of the variables that affected them the most was recreation. Despite having great wealth in their ecosystems, these do not contribute enough to their well-being, which was measured based on this indicator.

The previous idea is an example of why local indicators should be perfect and focus towards a better measurement of important social variables such as poverty and the well-being of the population for the sustainable management of resources.

The natural beauty and the benefits derived from ES in this area can and should make possible an increase in the quality of life of the inhabitants. It is fundamental to start valuing the use of these services and to internalize their benefits. By measuring poverty in its distinct dimensions, we place the value on our natural resources, and with proper management they can be used sustainably.

\section{REFERENCES}

[1] Costanza, R., D’Arge, R., De Groot, R., Farber, S., Grasso, M., Hannon, B., Limburg, K., Naeem, S., O`Neill, R., Paruelo, J., Raskin, R., Sutton, P. y van den Belt, M., The value of the world's ecosystem services and natural capital. Nature, 357, pp. 253-260, 1997. doi: http:// dx.doi.org/10.1038/387253a0

[2] Daily, G.C., Introduction: what are ecosystem services? Nature's Services: Societal Dependence on Natural Ecosystems, ed. G. Daily, Island Press: Washington, D.C. pp. 1-10, 1997.

[3] Bolund, P. y Hunhammar, S., Ecosystem services in urban areas. Ecological Economics, 29, pp. 293-301, 1999. doi: http://dx.doi.org/10.1016/S0921-8009(99)00013-0

[4] De Groot, R., Wilson, M., y Boumans, R., A typology for the classification, description and valuation of ecosystem functions, goods and services. Ecological Economics, 41, pp. 393-408, 2002. doi: http://dx.doi.org/10.1016/S0921-8009(02)00089-7

[5] Worm, B., Barbier, E., Beaumont, N., Duffy, J. E., Folke, C., Halpern, B., Jackson, J., Lotze, H., Micheli, F., Palumbi, S., Sala, E., Selkoe, K., Stachowicz, J. y Watson, R., Impacts of biodiversity loss on ocean ecosystem services. Science, 314, pp. 787-790, 2006. doi: http://dx.doi. org/10.1126/science.1132294

[6] Millennium Ecosystem Assessment. Ecosystems and Human-Being Synthesis, Island Press: Washington, DC, 2005.

[7] Sen, A., The possibility of social choice. The American Economic Review, 89(3), pp. 349-378, 1999.doi: http://dx.doi.org/10.1257/aer.89.3.349

[8] UNESCO, A Reference Guide on the Use of Indicators for Integral Coastal ManagementICAM Dossier I, IOC Manuals and Guides No. 45, 2003.

[9] The Economics of Ecosystem and Biodiversity, The ecological and economics foundations. UNEP-European Commission-German Federal Ministry for the Environment-UK Department for Environment, Food and Rural Affairs, 2010.

[10] Adams, W., Aveling, R., Brockington, D., Dickson, B., Elliott, J., Hutton, J., Roe, D., Vira, B. y Wolmer, W., Biodiversity conservation and the eradication of poverty. Science, 306, p. 1146, 2004.

[11] Duraiappah, A. Poverty and environmental degradation: A review and analysis of the nexus. World Development, 26(12), pp. 2169-2179, 1998. doi: http://dx.doi.org/10.1016/S0305750X(98)00100-4

[12] Jodha, N.S., Common property resources and rural poor in dry regions of India. Economic and Political Weekly, 21(27), pp. 1169, 1986. 
[13] Dasgupta, P. Environment and Resource Economics in the World of the Poor, Resources for the Future: Washington, DC, pp. 1-31, 1997. doi: http://dx.doi.org/10.2307/1912283

[14] Dasgupta, P., Gilbert, R. \& Stiglitz, J., Strategic considerations in invention and innovation: The case of natural resources. Econometrica, 51(5), pp. 1439-1448, 1983.

[15] Bene, C., Contribution of small scale fisheries to rural livelihoods in a water multi-use context (with a particular emphasis on the role of fishing as 'last resort activity' for the poor). FAO Fisheries Report No. 735, Supplement, pp. 20-49, 2003.

[16] Lawry, S.W., Tenure policy toward common property natural resources in Sun-Saharan Africa. Natural Resources Journal, 30, p. 403, 1990.

[17] Deacon, R., Assessing the relationship between government policy and deforestation. Journal of Environmental Economics and Management, 28, pp. 1-18, 1995. doi: http://dx.doi. org/10.1006/jeem.1995.1001

[18] Agrawal, A. y Redford, K., Poverty, Development and Biodiversity Conservation. Working Paper No. 26. Wildlife Conservation Society, 2006.

[19] García-Martínez, S. y Chávez-Ortiz, E., La pesquería de camarón en Puerto San Carlos: una perspectiva socioeconómica. Estudios ecológicos en Bahía Magdalena, eds. R. Funes-Rodríguez, J. Gómez-Gutiérrez, \& R. Palomares-García, CICIMAR-IPN: México, pp. 277-287, 2007.

[20] Gámez, A., Turismo y Sustentabilidad en Cabo Pulmo Baja California Sur, UABCSCONACYT, 2008.

[21] Olmos-Martínez, E., Beltrán-Morales, L., Breceda-Solís, A., Ortega-Rubio, A. y \& Salas, S., Riqueza ecológica y pobreza económica en un área natural protegida en Baja California Sur. Región y Sociedad, 20, pp. 133-164, 2008.

[22] Urciaga, J., Los servicios de los ecosistemas en el desarrollo (Capítulo 1). Recursos Marinos y Servicios Ambientales en el Desarrollo Regional, eds. J. Urciaga, L. Beltrán, \& D. Lluch, Centro de Investigaciones Biológicas del Noroeste, S. C. Universidad Autónoma de Baja California Sur, Centro Interdisciplinario de Ciencias Marinas-IPN, 2009.

[23] Sen, A., Poverty: an ordinal approach to measurement. Econometrica, 44(2), pp. 219-231, 1976. doi: http://dx.doi.org/10.2307/1912718

[24] Foster, J., Greer, J. y Thorbecke, E., A class of decomposable poverty measures. Econometrica, 52(3), pp. 761-766, 1984. doi: http://dx.doi.org/10.2307/1913475

[25] Anand, S. y Sen, A., Sustainable human development concepts and priorities. Trabajo Complementario. Informe de Desarrollo Humano, PNUD, 2004.

[26] Alkire, S. y Foster, J., Counting and multidimensional poverty measurement, OPHI Working, p. 7, 2007.

[27] SEDESOL, El Concepto de Desarrollo Humano, su Importancia y Aplicación en México, 2004.

[28] Székely, M. Desmitificación y nuevos mitos sobre la pobreza: Escuchando 'lo que dicen los pobres'. SEDESOL-Miguel Angel Porrúa Editor, 2005.

[29] Comisión Nacional de Áreas Naturales Protegidas, Available at www.islasgc.conanp.gob.mx/ igcbes.

[30] Ehrlich, P. y Ehrlich, A., The population bomb revisited. The Electronic Journal of Sustainable Development, 1(3), 2009.

[31] Instituto Nacional de Estadística y Geografía. Censo de Población y Vivienda, 2010.

[32] Alkire, S. y Santos, M.E., Acute multidimensional poverty: A new index for developing countries. Oxford Poverty \& Human Development Initiative (OPHI), Working Paper No. 38, 2010.

[33] Harrington, J.M., Health effects of shift work and extended hours of work. Occupational and Environmental Medicine, 58, pp. 68-72, 2001. doi: http://dx.doi.org/10.1136/oem.58.1.68

[34] Duclos, J.Y., Araar, A. y Fortin, C., DAD 4.6: A Software for Distributive Analysis. Universit Laval, 2010. 
[35] Consejo Nacional de Población. Índices de Marginación Estatales y Municipales, 2005.

[36] United Nations Development Programme. Indicadores de Desarrollo Humano y Género en México 2000-2005, BCS, pp. 47-54, 2005.

[37] Barragán, J.M., The coasts of Latin America at the end of the century. Journal of Coastal Research, 14(4), pp. 885-889, West Palm Beach, Florida, 2001.

[38] Fusco, A., On the definition and measurement of poverty: The contribution of multidimensional analysis. Centre D'etudes en Macroeconomie et FinanceInternationale, Available at http:// www.unice.fr/CEMAFI, 2003.

[39] Bourguignon, F., From income to endowments: the difficult task of expanding the income poverty paradigm, Centre National de la Recherche Scientifique, Departement et Laboratoire de Economie Theorique et Appliquee (DELTA)-World Bank, Working Paper 2003-03.

[40] FAO, Estado Mundial de la Pesca y la Acuacultura. Departamento de Pesca y Acuacultura, p. 203, 2006.

[41] United Nations Development Programme, Informe sobre Desarrollo Humano, 2007.

[42] Chávez, J.C., Tiempo Efectivo de Salida de la Pobreza, Estudios Económicos, número extraordinario, pp. 35-47, 2009.

[43] Cortés, F., Hernández, D., Hernández, E., Székely, M. y Vera, H., Evolución y características de la pobreza en México en la última década del siglo XX. Economía Mexicana, Nueva Época, 12(2), pp. 295-325, 2003.

[44] Hernández, E., Prospectiva Demográfica y Económica de México y sus Efectos sobre la Pobreza, CONAPO, 2002.

[45] López-Calva, L. y Rodríguez, L., Muchos Rostros, un Solo Espejo: Restricciones para la Medición Multidimensional de la Pobreza en México. Documento de Investigación, 20. SEDESOL, 2005.

[46] Morales, E., La evolución de la pobreza difusa multidimensional en México, Documento de Investigación del Banco de México, No. 2009-04, 2009.

[47] López-Calva, L. y Ortiz, E. Medición multidimensional de la pobreza en México: Significancia estadística en la inclusión de dimensiones no monetarias. Estudios Económicos, número extraordinario, pp. 3-33, 2008.

[48] Carbonell, M., Los derechos fundamentales de México. Instituto de Investigaciones Jurídicas. Serie Doctrina Jurídica, Número 185, 2004.

[49] Truong, K.D. \& Sturm, R., Weight gain trends across sociodemographic groups in the United Stated. American Journal of Public Health, 95(9), pp.1602-1606, 2005. doi: http://dx.doi. org/10.2105/AJPH.2004.043935

[50] Howarth, R. y Farber, S., Accounting for the value of ecosystem services. Ecological Economics, 41, pp. 421-429, 2002. doi: http://dx.doi.org/10.1016/S0921-8009(02)00091-5

[51] Atkinson, G., Sustainable development and policy: a brief review of the literature \& current practice, Final Report to the Government Economic Service Group on Sustainable Development, pp. 1-48, 2009.

[52] Alaluf, M., El empleo contra la cohesión social? Cuadernos Relaciones Laborales, No. 21, pp. 241-255, 2001.

[53] Perales, A., Lucha contra la pobreza e investigación científica. Gestión, Marzo, pp. 4-14, 2005.

[54] Consejo Nacional de Evaluación de la Política de Desarrollo Social, Available at www.internet. coneval.gob.mx/Informes/Interactivo/interactivo_entidades.swf.

[55] López-Feldman, A., Mora, J. y Taylor, E., Does natural resource extraction mitigate poverty and inequality? Evidence from rural Mexico and a Lacandon rain forest community. Environment and Development Economics, 12(2), pp. 251-269, 2006.doi: http://dx.doi.org/10.1017/ $\underline{\mathrm{S} 1355770 \mathrm{X} 06003494}$ 